\title{
컴프레션웨어의 디자인과 제품구성요소 분석
}

\author{
이정화 ${ }^{1)} \cdot$ 전정일 ${ }^{2)} \cdot$ 최경미 ${ }^{3)}$ \\ 1)배화여자대학교 패션디자인과 \\ ${ }^{2)}$ 가천대학교 의상학과 \\ 3)동서울대학교 패션디자인과
}

\section{An Analysis of Compression Wear Designs and Structural Elements}

\author{
Jung Hwa Lee ${ }^{1)}$, Jung Il Jun ${ }^{2)}$, and KuengMi Choi ${ }^{3) \dagger}$ \\ ${ }^{1)}$ Dept. of Fashion Design, Baewha Women's University; Seoul, Korea \\ ${ }^{2)}$ Dept. of Clothing, Gachon University Graduate School; Seongnam, Korea \\ ${ }^{3)}$ Dept. of Fashion Design, Dong-seoul College; Seongnam, Korea
}

\begin{abstract}
The aim of this study was to provide compression wear manufacture brands with information needed for product development. 8 tops and 7 bottoms from widely recognized compression wear manufacture brands were selected, and their product structural elements were analyzed, too. The results showed that most compression wear designs were applications of cutting lines designed considering muscle movements of the human body. The average number of cutting lines for patterns and designs were 14 for tops and 15 for bottoms. Different colored material was mainly used on the top for areas that require ventilation or high movement during sports for tops, and for areas that require muscle and joint support during sports for bottoms. The functionality of top materials were found to be stretch, muscle support, moisture absorption and high speed drying, warmth and ventilation for tops, in order of frequency, and stretch, muscle support, moisture absorption and high speed drying, and pressure for bottoms, in order of frequency. Tops were cut in the direction of the lengthwise grain, and bottoms were not only cut in the direction of the lengthwise grain, but also in the direction of the crosswise grain and bias for many products. Tops consisted of an average of 13 organically connected panels, and bottoms consisted of an average of 18 organically connected panels, which was analyzed to improve functionality. The average clothing surface area stretch rate was $85.7 \%$ for tops and $70.0 \%$ for bottoms, indicating that bottoms were designed to have higher strain rates compared to tops.
\end{abstract}

Key words : compression wear(컴프레션 웨어), design(디자인), product structural elements(제품구성 요소), functional patterns(기능성 패턴)

\section{1. 서 론}

건강과 레저에 대한 관심이 높아져 전문스포츠 선수뿐 아니 라 일반인들도 다양한 스포츠분야에 참여하게 되면서, 스포츠 인구가 증가하고 스포츠웨어 시장은 전문화 - 세분화되어 양 적 - 질적으로 꾸준히 성장하고 있는 추세이다. 이러한 경향에 맞추어 일반인들에게도 운동의 효과를 향상시켜주는 컴프레션 웨어의 관심이 높아지고 사용 범위가 확대되고 있다. 컴프레션 웨어는 런던 올림픽에 출전했던 국가대표 축구 선수들이 유니 폼 안쪽에 입고 나와 눈길을 끌었던 제품으로 프로 골프선수나 야구선수들이 입으면서 더욱 이슈화된 기능성 스포츠웨어 중 하나이다. 일반 스포츠웨어와는 달리 운동 능력을 향상 시키는 기술이 적용된 최첨단 기능성 스포츠웨어로, 운동할 때 주로 사

$\dagger$ Corresponding author; KuengMi Choi

Tel. +82-31-720-2186, Fax. +82-31-720-2295

E-mail: orogi1961@hanmail.net
용되는 근육에 보다 더 많은 산소를 공급해 운동의 효과를 극 대화시키는 기능이 있다고 알려져 있으며 이는 최근 논문에서 증명되고 있다(Koo, 2011). 또한 제 2의 피부라고 불릴 정도로 경량화된 소재와 강한 압박감, 부드러운 착용감이 운동 후 피 로를 억제하고 신체의 빠른 회복을 돕는 기능적 역할을 한다고 각 브랜드마다 보도하고 있다.

1996년 미국에서부터 시작된 컴프레션웨어는 선수들의 운동 능력 향상에 도움이 된다는 보도가 되면서 기존의 세계적인 스 포츠웨어 기업들도 컴프레션웨어를 생산하기 시작하였고 지금 은 각 회사가 독자적인 기술 영역을 구축하고 해마다 신제품을 내놓고 있다(Donga, 2013). 국외 컴프레션웨어 브랜드로는 최 초 컴프레션웨어 브랜드인 Under Armour(미국), 하이퍼포먼스 운동선수들의 압도적인 지지를 받고 있으며 2012년 국내 판매 를 시작한 Skins(호주), Nike Pro(미국), Adidas Techfit(독일), Descente(일본)등이 대표적이며, 국내 컴프레션웨어 브랜드로는 충남대학교 연구진과 합작으로 개발된 Prospecs Base Layer와 
Scelido 등이 대표적이다. 이러한 컴프레션웨어는 운동선수 이 외에도 최근 일반 소비자들에게 큰 관심을 얻고 있다. 중장년 층에서는 운동효과 항상기능은 물론 피로도억제 및 근육보호기 능을 위해 주로 착용하고 있으며 젊은층에서는 운동효과 향상 기능과 함께 스포츠웨어로 컴프레션웨어가 조금씩 자리잡고 있 는 추세이다.

국내에서 발표된 컴프레션웨어에 관한 연구를 보면, 컴프레 션웨어 패턴설계 및 제품개발에 대한 연구에는 $\mathrm{Cha}(2013)$, Choi(2004), Jeong(2006), Jeong et al.(2010), Jeong and Hong(2006), Kim et al.(2012), $\operatorname{Kim}(2012), \operatorname{Kim}(2008)$ 등이 있으며 기능성 소재나 스포츠웨어 소재에 관한 연구에는 Baik and $\operatorname{Kim}(2005)$, Lee and $\operatorname{Baik}(2008)$ 등이 있다. 이와 같이 컴프레션웨어는 기능성 소재 및 입체패턴을 중심으로 주로 연 구되어 왔지만 컴프레션웨어에 초점을 맞춘 연구는 아직 많이 부족한 실정이며 컴프레션웨어 개발을 위한 보다 다양한 측면 에서의 연구가 필요한 것이 현실이다.

이에 본 연구에서는 현재 국내외에서 전개 중인 남성용 컴 프레션웨어 생산브랜드를 선별하여 절개선의 위치와 수를 중심 으로 한 디자인분석, 생산사이즈, 가격, 소재 등을 중심으로 한 제품구성요소 분석 및 정량적 패턴분석을 통해 컴프레션웨어 제품의 디자인요소와 생산요소 및 기능적 요소로 세분화된 고 기능성 컴프레션웨어의 개발방항을 제시하고자 한다.

\section{2. 연구 방법}

\section{1. 연구대상}

현재 국내외에서 전개 중인 컴프레션웨어 생산브랜드 중 14 개의 제품 중에서 상의 18 개와 하의 23 개에 대한 남성용 컴프 레션웨어 제품을 대상으로 전반적인 컴프레션웨어 제품에 대한 실태를 조사하여 디자인분석과 제품구성요소분석을 실시하였고, 컴프레션웨어 생산브랜드 중 인지도가 있는 상의 8 개, 하의 7 개 의 제품을 선별하여 제품치수 및 패턴분석을 실시하였다.

\section{2. 조사항목 및 연구방법}

제품의 디자인경향과 제품의 구성요소 경향을 파악하기 위 하여 총 41 개 제품(상의 18 개, 하의 23개)을 대상으로 디자인 분석과 제품구성요소 분석을 실시하여 제품의 전반적인 제조 경항을 파악하였다.

디자인 분석은 옷길이와 절개선의 위치와 수를 정량적으로 분석하고 절개선에 따른 근육의 배치를 파악하여 컴프레션웨어 설계 시 근육과 관절의 위치를 고려한 디자인과 패턴 개발의 기초 자료를 제시하였다. 상-하의 절개선과 인체 근육의 위치 를 분석하기 위한 남성 인체의 근육도는 Fig. 1과 같다.

제품구성요소 분석에서는 생산사이즈와 가격, 사용 소재와 컬러 경향을 조사 분석하고, 기능성 의류인 컴프레션웨어의 주 요 기능성과 봉제방법을 조사하여 컴프레션웨어 개발에서 요구 되는 제품의 구성요소 경향을 파악하였다.

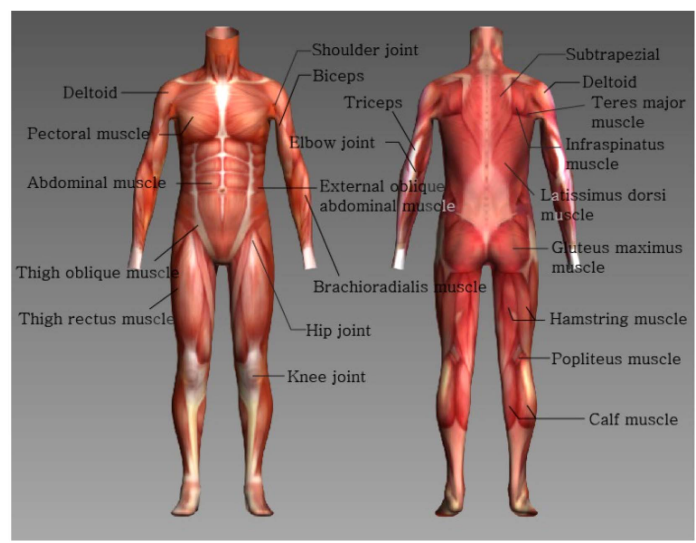

Fig. 1. Diagram of body muscles.
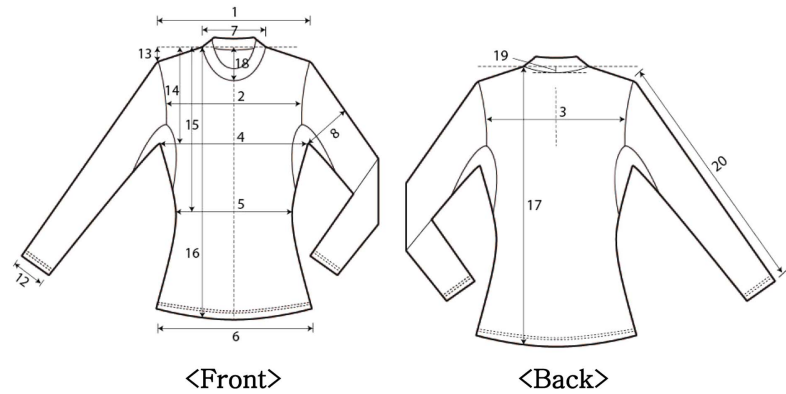

Fig. 2. Flat showing product measurement indexes for tops.

패턴분석은 총 15 개 제품(상의 8 개, 하의 7 개)의 제품치수를 측정하고 시접을 포함하도록 분해하여 패턴을 복사하고 재단방 향을 파악하여 제품별 유사패턴을 재설계하였다. 제품치수측정 에 기준되는 상-하의 도식화는 Fig. 2, Fig. 3에, 상-하의 제 품치수항목 및 측정방법은 Table 1, Table 2에 나타내었다. 각 제품의 유사패턴에 대한 패턴의 정량적 분석을 위하여 가상 피
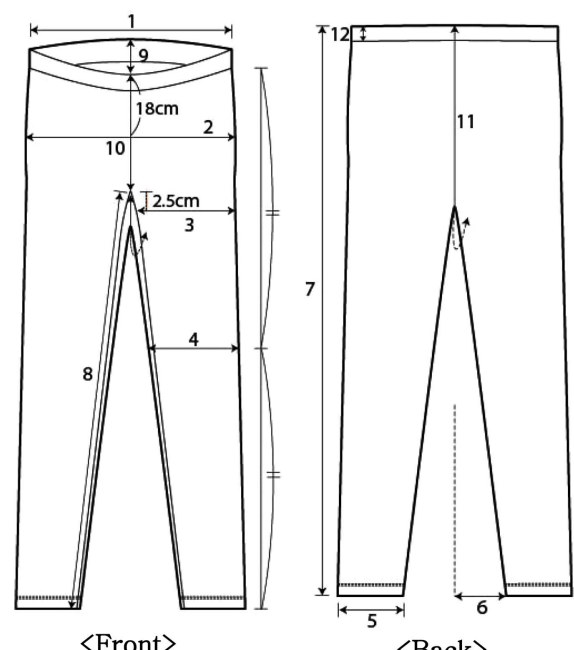

Fig. 3. Flat showing product measurement indexes for bottoms. 
Table 1. Product measurement categories and methods for compression wear tops

\begin{tabular}{|c|c|c|c|}
\hline & & Category & Measurement method \\
\hline \multirow{12}{*}{$\begin{array}{l}\text { Horizontal } \\
\text { measurement } \\
\text { index }\end{array}$} & 1 & Shoulder width & Horizontal length between left and right shoulder edge points. \\
\hline & 2 & Front width & Horizontal length between front armhole middle points. \\
\hline & 3 & Back width & Horizontal length between back armhole middle points. \\
\hline & 4 & Chest girth & Twice the horizontal length between the armhole bottom points. \\
\hline & 5 & Waist girth & Twice the horizontal length from the side line to the point on the thinnest spot. \\
\hline & 6 & Hem girth & Twice the horizontal length between the side line end points. \\
\hline & 7 & Neck width & Horizontal length between the left and right HPS. \\
\hline & 8 & Upper armhole girth & $\begin{array}{l}\text { Twice the horizontal length where the armhole bottom point (mark) meets the sleeve folding line at a right } \\
\text { angle. }\end{array}$ \\
\hline & 9 & Folded sleeve width & Horizontal length of sleeve width when gore under armhole is folded towards the bodice. \\
\hline & 10 & $\begin{array}{l}\text { gore below armhole length } \\
\text { (horizontal) }\end{array}$ & Length of straight horizontal line when gore under armhole is folded flat. \\
\hline & 11 & $\begin{array}{l}\text { gore below armhole length } \\
\text { (vertical) }\end{array}$ & Length of straight vertical line when gore under armhole is folded flat. \\
\hline & 12 & Sleeve hem girth & Twice the length of the sleeve hem. \\
\hline \multirow{7}{*}{$\begin{array}{l}\text { Vertical } \\
\text { measurement } \\
\text { index }\end{array}$} & 13 & Shoulder slope & Vertical length from HPS to the horizontal line from the shoulder end point. \\
\hline & 14 & Armhole depth from HPS & Vertical length from HPS to the horizontal line from the armhole bottom point. \\
\hline & 15 & Waist location from HPS & Vertical length from HPS side line to the point on the thinnest spot. \\
\hline & 16 & Front bodice length from HPS & Vertical line from HPS to the front bodice hem. \\
\hline & 17 & Back bodice length from HPS & Vertical length from HPS to the back bodice hem. \\
\hline & 18 & Front neck slope & $\begin{array}{l}\text { Vertical length from the middle of the horizontal line that connects the left and right HPS to the front neck } \\
\text { middle slope location. }\end{array}$ \\
\hline & 19 & Back neck slope & $\begin{array}{l}\text { Vertical length from the middle of the horizontal line that connects the left and right HPS to the back neck } \\
\text { middle slope location. }\end{array}$ \\
\hline Other & 20 & Sleeve length & Length from the shoulder end point to the sleeve hem. \\
\hline
\end{tabular}
HPS : High Point Shoulder

팅을 이용한 착의평가와 패턴 변형율을 분석하기 위해 CLO 3D 20113.83 프로그램을 사용하였고 40대 표준 남성의 체표 면적과 제품면적을 비교하기 위하여 Rapidform XOR 3
Program을 사용하여 분석하였다. 가상 피팅과 체표면적 분석에 사용된 가상모델은 핏 앤 바디와 동서울대학교(2009)가 공동으 로 개발한 40 대 남성 표준 인체형상을 사용하였다.

Table 2. Flat showing product measurement indexes for bottoms

\begin{tabular}{|c|c|c|}
\hline \multicolumn{2}{|r|}{ Category } & Measurement method \\
\hline \multirow{6}{*}{$\begin{array}{l}\text { Horizontal } \\
\text { measurement } \\
\text { index }\end{array}$} & 1 Waist girth & Twice the horizontal length between the two waist end points. \\
\hline & 2 Hip girth & $\begin{array}{l}\text { Twice the length from the point } 18 \mathrm{~cm} \text { down from the waist band end point of the front } \\
\text { crotch line to the point where the line meets the side line at a right angle. }\end{array}$ \\
\hline & 3 Thigh girth & $\begin{array}{l}\text { Twice the length from the point } 2.5 \mathrm{~cm} \text { down from the crotch point to the inner leg line, } \\
\text { to the point where the line meets the side line at a right angle. }\end{array}$ \\
\hline & 4 Knee girth & $\begin{array}{l}\text { Horizontal length of knee width (middle of length from under waistband to trouser hem, } \\
\text { knee design standard). }\end{array}$ \\
\hline & 5 Trouser hem girth & Twice the length between the two trouser hem end points. \\
\hline & 6 Horizontal inseam gap length & Horizontal length from center front line to trouser hem inseam. \\
\hline \multirow{6}{*}{$\begin{array}{c}\text { Vertical } \\
\text { measurement } \\
\text { index }\end{array}$} & 7 Total length & Side line length from waistband to trouser hem. \\
\hline & 8 Inseam & Inside length from crotch point to trouser hem. \\
\hline & 9 Front and back waistband height difference & Difference between back and front waistbands from center front. \\
\hline & 10 Front crotch & Center front length from waistband to crotch point. \\
\hline & 11 Back crotch & Center back length from waistband to crotch point. \\
\hline & 12 Waistband height & Vertical waistband length. \\
\hline
\end{tabular}


또한 부위별 제품면적과 패턴형태, 봉제방법을 파악하기 위해 제품을 분해하여 Yuka Pattern Making Program(Super ALPHA: Plus 2.50)으로 디지타이징하여 패턴을 입력하고 부위별 면적과 패턴 형태를 분석하였다. 본 연구 자료의 통계분석은 SPSS 12.0 통계프로그램으로 처리하였고 조사항목의 평균값과 표준편차 및 빈도분석을 통해서 각 제품을 비교 · 분석하였다.

\section{3. 결과 및 논의}

\section{1. 컴프레션웨어의 디자인 분석}

\subsection{1. 디자인}

컴프레션웨어 상의의 소매길이는 $61 \%(11$ 개 제품)가 10 부 소 매였으며, 반팔과 9부 순으로 나타났다. 소매형태는 $59 \%(9$ 개 제품)가 라글란 소매이고 나머지는 셋인 소매로 나타났으며, 네 크라인은 밴드 형태의 네크라인과 $1: 1$ 립조직으로 된 라운드 네크라인의 디자인이 많았다. 브랜드 나염 로고 위치를 살펴보 면, 앞판의 바짓부리 좌측, 뒷중심 네크라인 아래, 소매통, 앞-
뒤 네크라인(밴드)에 주로 위치하는 경향을 보였다. 절개선 및 디자인의 기능을 동시에 가지고 근육을 압박하여 근육의 힘을 집중시켜 근육 통증과 부상 방지를 위한 실리콘 테이프 프린트 의 경우, $27 \%$ 가 등 부위에 접착되었고 배, 허리, 어깨부위의 순으로 실리콘 테이프 프린트를 사용하고 있었다.

컴프레션웨어 하의는 $52 \%(12$ 개 제품)가 9 부 길이였으며, 10 부와 5 부(무릎아래) 순으로 나타났다. 허리밴드는 라이크라 허 리밴드와 제 원단 허리밴드의 안쪽에 스트링이 있는 디자인이 많았다. 브랜드 나염 로고의 위치를 살펴보면, 넙다리, 장딴지, 옆선 위쪽에 주로 위치하는 경향을 보였다.

컴프레션웨어는 인체의 운동을 고려하여 설계된 절개선을 응 용한 디자인이 대부분이며 디테일은 실리콘 테이프나 프린트, 배색봉사 등 착용감에 최대한 영향을 주지 않고 인체에 밀착되 어 돌출되지 않도록 디자인되었다.

3.1.2. 절개선 위치 및 수

컴프레션웨어 디자인선을 파악하기 위하여 상의 18 개 제품,

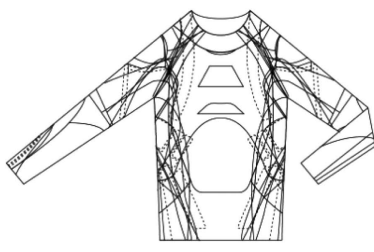

$<$ Front $>$

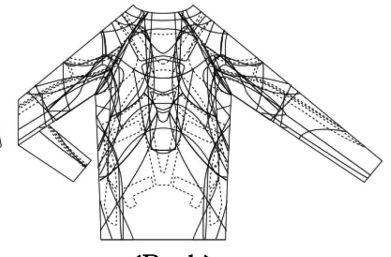

$\langle$ Back $>$

Tops(number of products $=18$ )

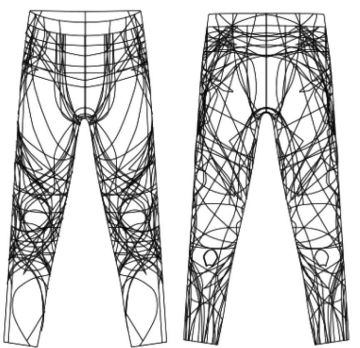

$\langle$ Back>

Bottoms (number of products $=23$ )

Fig. 4. Analysis of compression wear seams as a part of design.
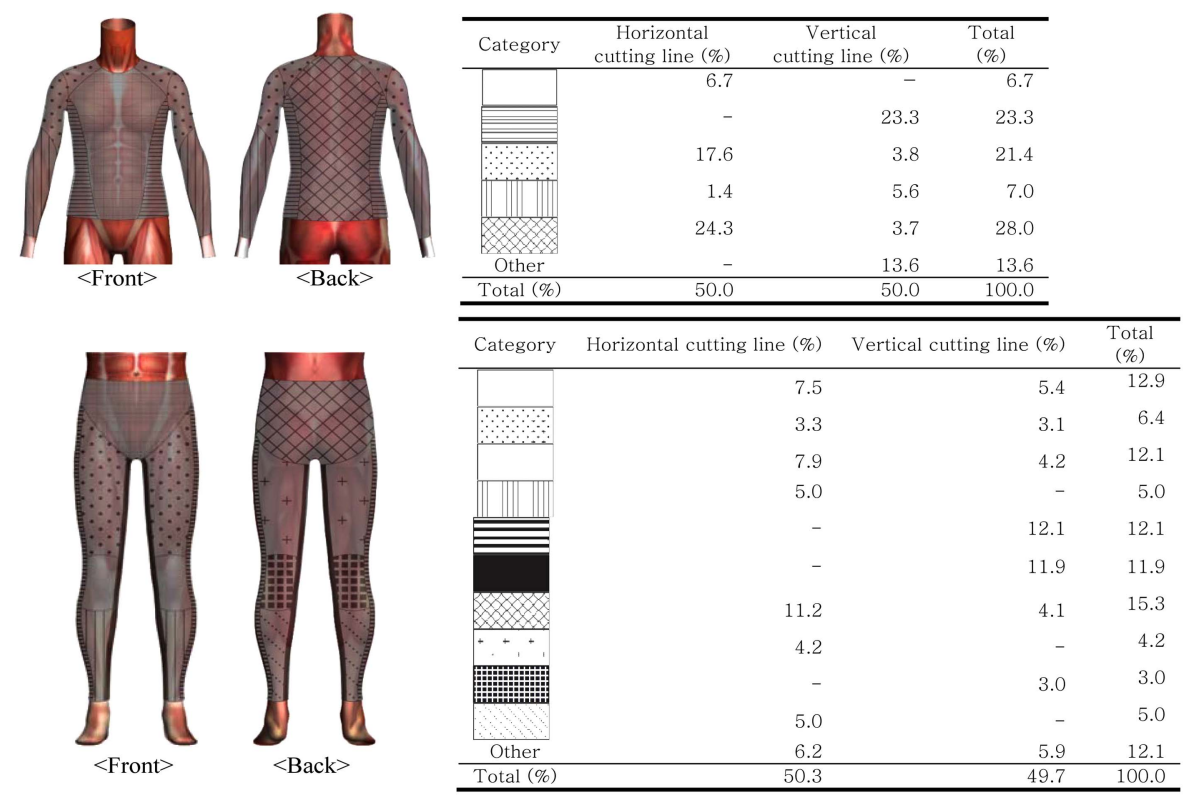

Fig. 5. Frequency of compression wear cutting lines. 
하의 23 개 제품의 상 - 하의 절개선의 위치와 수를 분석한 결 과를 Fig. 4에 제시하였고 절개선은 실선으로, 테이핑은 점선으 로 구분하여 나타내었다. 상 - 하의를 나누어서 디자인 절개선 의 수를 조사한 결과, 상의는 평균 14 개의 절개선으로 구성되 었고 그 중 가로 절개선이 3 개, 세로 절개선이 11 개로 나타났 다. 상의에 나타난 가로 절개선의 위치는 등, 뒷목둘레아래, 앞 판 어깨, 앞판 밑단의 순으로 나타났고, 상의에 나타난 세로 절 개선의 위치는 앞판 진동 프린세스라인, 소매 인심, 앞판 옆선 에서 밑단까지 이어지는 라인, 뒤판 진동 프린세스라인 순으로 나타났다.

컴프레션웨어 하의는 평균 15 개의 절개선으로 구성되었고 그 중 가로 절개선이 5 개, 세로 절개선이 10 개로 나타났다. 하의 에 나타난 가로 절개선의 위치는 앞판 무릎과 허리, 뒤판 허리 부분의 순으로 나타났고 세로 절개선의 위치는 앞판쪽으로 넘 어가는 옆선과 인심, 밑위, 뒤판쪽으로 넘어가는 옆선과 인심의 순으로 나타났다. 하의의 경우 $65 \%$ 가 허리밴드 절개선이 있는 제품이었고 나머지는 절개선 없이 몸판과 이어지는 제품이었다. 또한 앞중심선이 있는 제품과 없는 제품의 빈도는 같았고 뒷중 심선이 있는 제품은 $57 \%$ 로 뒷중심선이 없는 제품과 거의 같은 빈도를 나타내었다. 이와 같은 결과를 남성 근육 형상에 부위 별로 구분하여 상 - 하의 빈도를 나타내면 Fig. 5와 같다.

이와 같이 분석한 상 - 하의 절개선을 남성 인체의 근육명 (Fig. 1)을 기준으로 정리해 보면 다음과 같다. 상의 가로 절개 선은 넓은 등근(등), 승모근(뒷목아래), 앞삼각근(앞판어깨), 배 곧은근(앞판밑단) 등의 방향을 중심으로 주로 구성되었고 상의 디자인 절개선 중에서 가로 절개선의 빈도가 높은 부위는 몸판 앞 - 뒤와 어깨부위였다. 앞몸판의 경우 배곧은근의 방향에 근 거해 절개선을 설정함으로써 몸통 굽히기, 서 있는 자세유지에 도움을 주고 뒷몸판의 경우 등세모근과 넓은 등근의 방향을 중 심으로 절개선을 설정함으로써 허리와 목의 자세유지에 도움을 주고 있다. 어깨의 경우 삼각근을 가로 절개선으로 잡아주어 어 깨관절운동에 도움을 주는 것으로 분석되었다.

상의 세로 절개선은 배바깥빗근(앞프린세스), 상완두갈래근(소 매인심), 배바깥빗근(앞판옆선 밑단), 가시아래근(뒤프린세스) 등 의 방향을 중심으로 주로 구성되었고 상의 디자인 절개선 중에 서 세로 절개선의 빈도가 높은 부위는 몸판측면과 팔부위였다. 몸판측면의 경우 배바깥빗근의 방향을 중심으로 절개선을 설정 함으로써 몸통의 운동과 자세유지에 도움을 주고 팔부위의 경 우 상완요골근의 방향을 중심으로 절개선을 설정함으로써 팔굽 관절과 요골척골관절을 잡아주어 운동 시 과도한 손목관절 사 용에 따른 부상 방지에 도움을 주는 것으로 분석되었다.

하의 가로 절개선은 무릎관절(앞무르), 넙적다리비스듬근(허 리), 넓은등근(뒤판허리)의 방향을 중심으로 주로 구성되었고 하의 디자인 절개선 중에서 가로 절개선의 빈도가 높은 부위는 무릎과 엉덩이부위였다. 무릎의 경우 무릎관절에 근거해 절개 선을 설정함으로써 무릎운동에 도움을 주고 엉덩이의 경우 골 반, 엉덩관절 및 무릎관절의 버팀목이 되는 큰 볼기근의 방향
을 중심으로 절개선을 설정함으로써 하체 운동 시 엉덩관절은 물론 하체의 균형과 안정에 도움을 주는 것으로 분석되었다.

하의 세로 절개선은 넙적다리곧은근(앞으로 넘어가는 옆선), 대내전근(앞으로 넘어가는 인심), 봉공근(밑위), 반건양근(뒤로 넘어가는 인심)등의 방향을 중심으로 주로 구성되었고 하의 디 자인 절개선 중에서 세로 절개선의 빈도가 높은 부위는 인심과 옆선부위였다. 인심과 옆선의 경우 대내전근과 반건양근의 방 향을 중심으로 세로 절개선을 설정함으로써 넙다리 안팎 근육 을 지지하고 고관절과 무릎관절을 이어 전반적인 다리운동에 도움을 주는 것으로 분석되었다.

이와 같이 현재 생산되고 있는 14 개 브랜드의 컴프레션웨어 의 디자인과 절개선의 위치 및 수를 분석한 결과, 컴프레션웨 어의 디자인은 인체에 밀착되어 착용감에 최대한 영향을 주지 않고 인체의 근육 움직임을 고려하여 설계된 절개선을 응용한 디자인이 대부분이었다. 상의는 평균 14 개의 절개선으로 구성 되었고 그 중 가로 절개선이 3 개, 세로 절개선이 11 개로 나타 났고, 하의는 평균 15 개의 절개선으로 구성되었고 그 중 가로 절개선이 5 개, 세로 절개선이 10 개로 나타났으며 각 절개선은 근육과 관절의 위치를 고려하여 설계되었음을 알 수 있었다. 이 는 컴프레션웨어에 설정된 주요 디자인 절개선을 기준으로 패 턴을 블록화하여 근육의 역할과 놓임 방향 및 관절의 움직임을 고려한 압박량을 차별화할 수 있는 패턴 개발과 블록화 한 패 턴의 소재 선정에 따라 부위별 기능성을 달리할 수 있는 맞춤 형 컴프레션웨어의 개발 자료가 될 것이다.

\section{2. 컴프레션웨어의 제품구성요소 분석}

\subsection{1. 생산사이즈 및 가격 실태}

컴프레션웨어 상 - 하의의 생산 사이즈 스펙 수의 기준 및 가격 실태를 Table 3에 나타내었다. 상의의 생산 사이즈는 $\mathrm{S}$, $\mathrm{M}, \mathrm{L}$ 로 문자 호칭으로 생산하는 브랜드가 다수였고 사이즈 스 펙 수를 3 개로 전개하는 제품이 $50 \%$ 로 가장 많았다. 다음으로 4 개 사이즈, 5 개 사이즈로 전개하는 제품 순으로 나타났다. 컴 프레션웨어 상의의 평균 가격대는 5 10만원인 제품이 $50 \%$ 를 차지했고 10 15만원, 15 20만원의 순으로 나타났다.

컴프레션웨어 하의의 생산 사이즈도 $\mathrm{S}, \mathrm{M}, \mathrm{L}$ 로 문자 호칭으 로 생산하는 브랜드가 다수였고 기타에 90,95 등 치수호칭이 포함되었다. 사이즈 스펙 수는 4 개로 전개하는 제품이 $56.5 \%$ 로 가장 많았고 다음으로 6 개 사이즈, 5 개 사이즈로 전개하는 제품 순으로 조사되었다. 컴프레션웨어 하의의 평균 가격대는 15 20만원인 제품이 가장 많았고 5 10만원, 10 15만원의 순으 로 나타났다.

컴프레션웨어의 생산 사이즈 스펙 수는 상의에 비해 하의 사 이즈 전개 범위가 넓은 것으로 분석되고 상의는 3 개, 하의는 4 개로 전개하는 제품이 $50 \%$ 이상을 차지했다. 제품의 평균 가 격대는 상의 5 10만원, 하의 15 20만원으로 상의보다는 하의 가 더 높은 가격대를 나타냈다.

Table 4는 브랜드별 컴프레션웨어 생산 사이즈 및 기준 사이 
Table 3. Compression wear manufacture size standards and prices

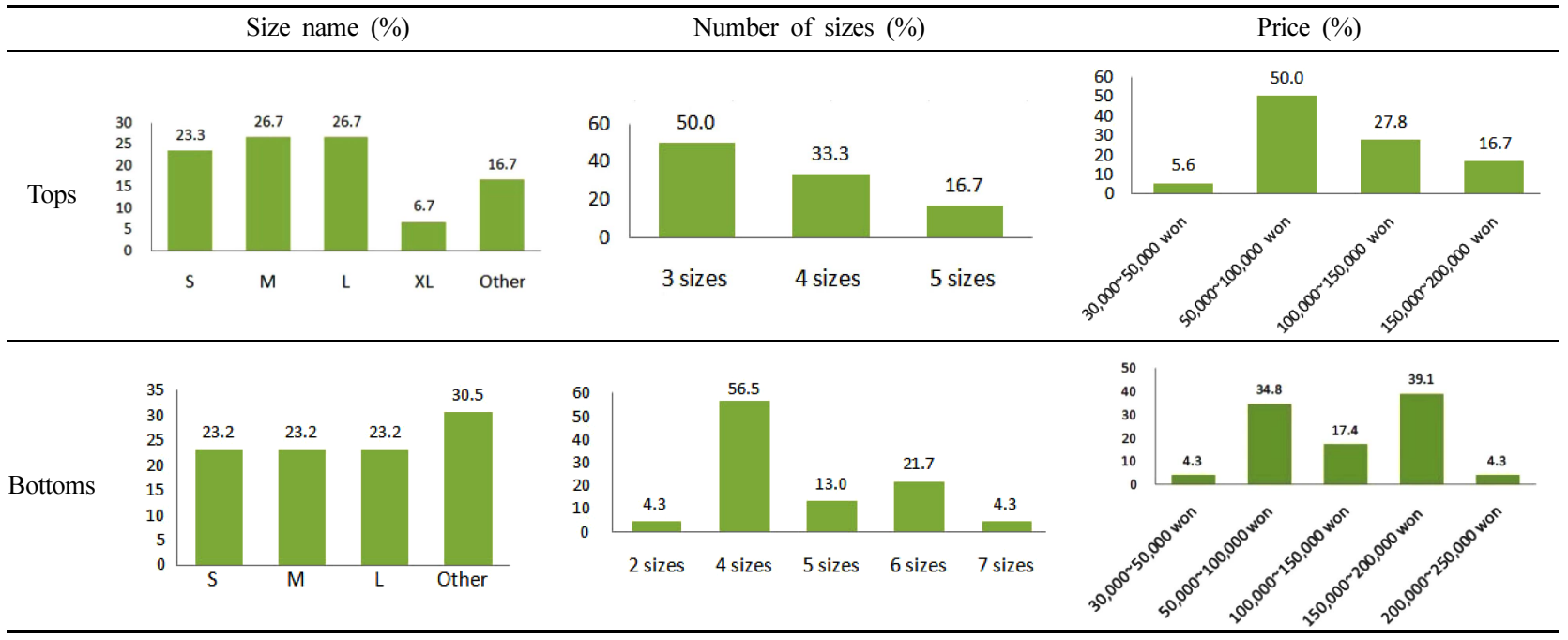

Table 4. Manufacture size range and standard sizes according to brand $<$ Tops $>$

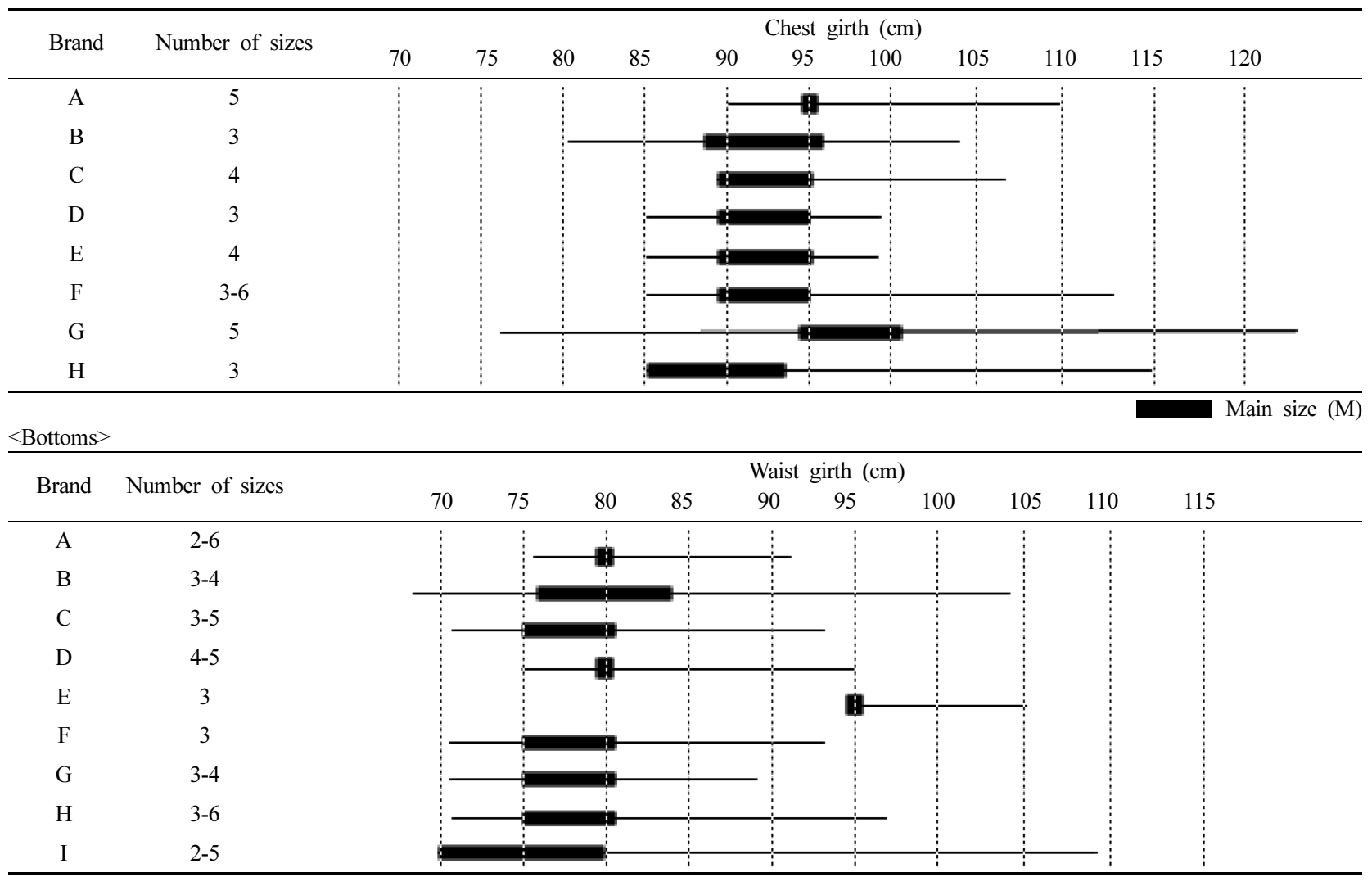

즈의 범위를 나타낸 결과이다. 상의는 가슴둘레를 기준으로 제 품 사이즈를 구분하는 브랜드가 대부분이었고 작게는 $76 \mathrm{~cm}$ 부 터 크게는 $124 \mathrm{~cm}$ 까지 수용하는 사이즈 범위를 설정하고 있었 고 90 100 cm가 가장 많이 생산하고 있었다. 각 브랜드별 기 준 사이즈의 범위는 대부분 가슴둘레 90 95 cm를 기준으로 설 정하는 것으로 나타났다. 하의는 허리둘레를 기준으로 제품 사
이즈를 구분하는 브랜드가 대부분이었고 작게는 $68 \mathrm{~cm}$ 부터 크 게는 $109 \mathrm{~cm}$ 까지 수용하는 사이즈 범위를 설정하고 있었고 $85 \sim 5 \mathrm{~cm}$ 를 가장 많이 생산하였다. 각 브랜드별 기준 사이즈의 범위는 대부분 허리둘레 $75 ~ 80 \mathrm{~cm}$ 를 기준으로 설정하는 것으 로 나타나 상의에 비해 하의 제품의 사이즈가 작게 설정되고 있는 경향을 보였다. 
Table 5. Location and trends of different colored material on compression wear

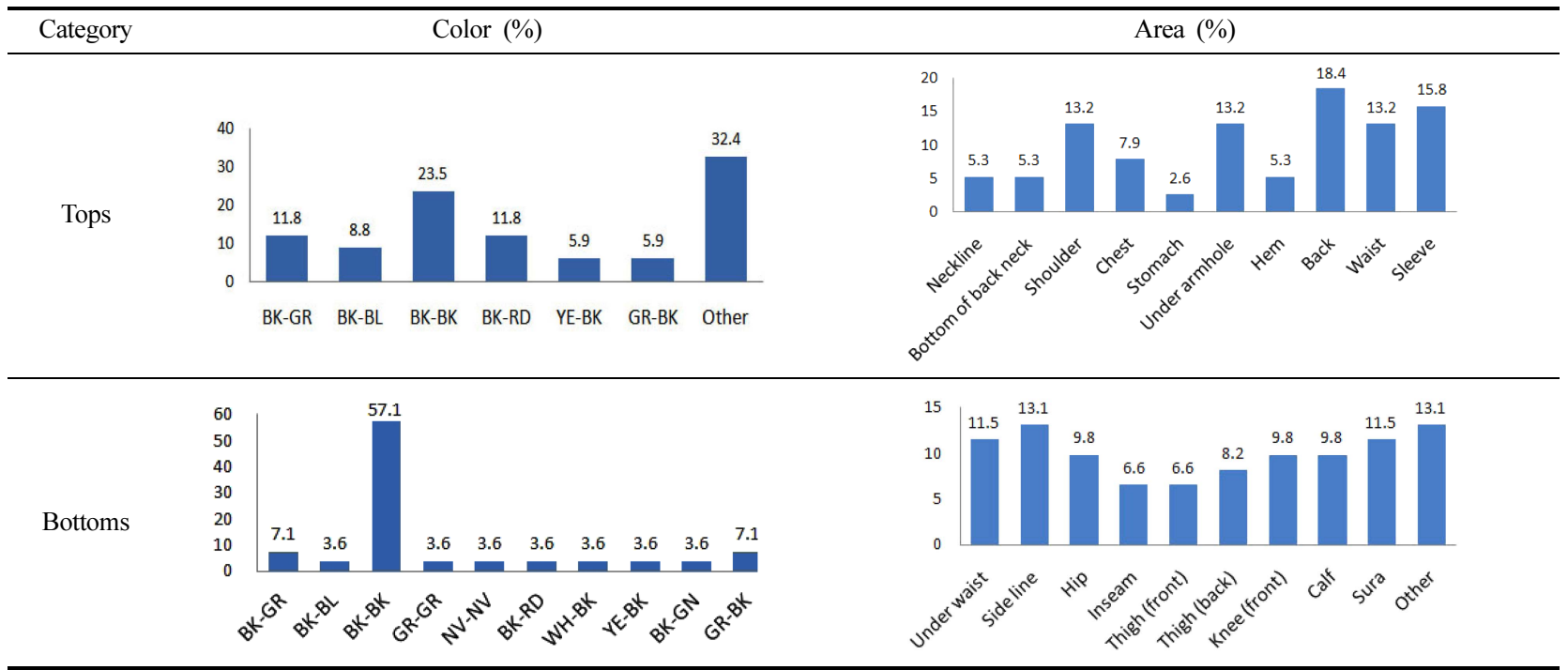

Code: YE: yellow, NV: navy, WH: white, GN: green

3.2.2. 사용 소재 및 컬러 실태

최근 브랜드에서는 컴프레션웨어에 사용되는 경량 기능성 소 재를 개발하여 신소재명과 소재 기능성을 부각시켜 소비자의 관심을 끌고 있다. 컴프레션웨어에 주로 사용되고 있는 소재에 는 클라이마웜(A제품), 클라이마쿨(A제품), 드라이핏(N제품), 드 라이존(S제품), 드라이메쉬(U제품)등이 있으며 고어텍스, 파워 스트레치 소재도 많이 사용되고 있다.

컴프레션웨어는 상 - 하의 모두 겉감과 배색감 1 종류, 총 2 종류의 소재를 사용하여 제품을 제작하는 경향이 강했고 배색 감 2 종류를 사용하여 총 3 종류의 소재를 사용하는 제품도 26 31\%로 나타났다. 겉감 소재는 솔리드 조직, 배색감은 솔리 드와 네트조직이 많이 보였다. 상의 배색감 컬러는 겉감 $\mathrm{BK}$ (Black)에 배색감 $\mathrm{BK}$ 인 제품이 가장 많았고 BK-GR(Grey), $\mathrm{BK}-\mathrm{RE}$ (Red), BK-BL(Blue)의 순으로 나타났으며 하의 배색감 컬러도 겉감 $\mathrm{BK}$ 에 배색감 $\mathrm{BK}$ 인 제품이 $57.1 \%$ 로 반 이상을 차지했으며 BK-GR, GR-BK의 순으로 보여졌다(Table 5). 상 의 배색감은 등, 소매, 어깨, 진동밑, 허리 등에 주로 사용되었 고 하의 배색감은 옆선, 허리아래, 장딴지, 엉덩이, 앞무릎, 종 아리 등에 주로 사용되었다.

컴프레션웨어는 초경량성 고어텍스나 파워 스트레치 소재로 많이 제작되었고 상-하의 컬러는 주로 모노톤과 비비드한 컬 러의 경향으로 분석되었다. 상의 배색감은 통기성 및 운동 시 활동성을 요하는 부위에 주로 사용되어 기능성을 부여하고 하 의 배색감은 운동 시 근육 및 관절 서포트가 필요한 부위에 주로 사용되어 운동 시 인체를 지지하는 것으로 분석되었다.

\subsection{3. 요구 기능성 실태}

컴프레션웨어는 운동의 효과를 극대화시키고자 하는 목적으 로 개발된 기능복으로 입체패턴 전개 및 소재의 기능성이 컴프
레션웨어 기능에 큰 역할을 차지하고 있다. S제품은 Bio Acceleration Technology(부위별 차등압박기술)로 근육 파워를 극대화시키는 기능과 강화된 산소 공급으로 피로도를 감소시키 는 기능이 있다고 보도되고 있고 U제품의 소재는 체온 조절이 가능하여 시원하고 건조한 상태를 유지할 수 있으며 수분조절, 향균방취, 자외선차단의 기능이 있다고 알려져 있다. 또한 유기 적으로 연결된 패널들로 구성되어 동작 기능성을 향상시키고 인체구조에 기초하여 개발되어 스피드와 퍼포먼스 향상 시키는 기능을 가졌다고 한다. N제품은 쿨링 기능으로 최상의 컨디션 을 유지할 수 있고 주요 발열 부위(어깨, 겨드랑이, 등)에 오픈 형 메쉬 소재를 사용하여 통기성, 흡습속건성을 극대화시키는 기능이 있다고 보도되고 있다.

이러한 컴프레션웨어 제품들이 제시하고 있는 다양한 기능 성을 조사한 결과는 Fig. 6에 나타내었다. 상 - 하의 모두 신축 성과 땀을 효과적으로 흡수하고 쾌속 건조시켜 피부를 쾌적한 상태로 유지시키는 흡습속건 기능이 높은 빈도를 나타내었다. 근육운동을 하면 다량의 에너지가 소비되고 열생산을 수반하여 체온이 올라가고 체온조절을 위해 땀이 나게 된다. 또한 온열 성 발한은 체간부 앞뒤 양면보다 사지에서 적게 발생한다(Choi $\& \mathrm{Kim}, 2011)$. 상의의 경우 호흡기관이 위치해 있으므로 체온 조절을 위한 보온 기능의 빈도가 하의보다 높았다고 판단되며 활동시 발열 부위를 위한 통기성 기능도 나타났다. 하의의 경 우 사지부위는 주로 근육으로 이루어져 있어 상의에 비해 압박 기능의 빈도가 높아 하의가 상의보다 압박성이 있다고 판단할 수 있었다. 기타에는 방수성, 방취성, 향균성 등이 있었다.

\subsection{4. 봉제 방법 실태}

컴프레션웨어 제품의 상 - 하의 부위별 봉제 방법을 분석하 여 솔기와 스티치의 빈도가 가장 높은 봉제 방법을 부위별로 


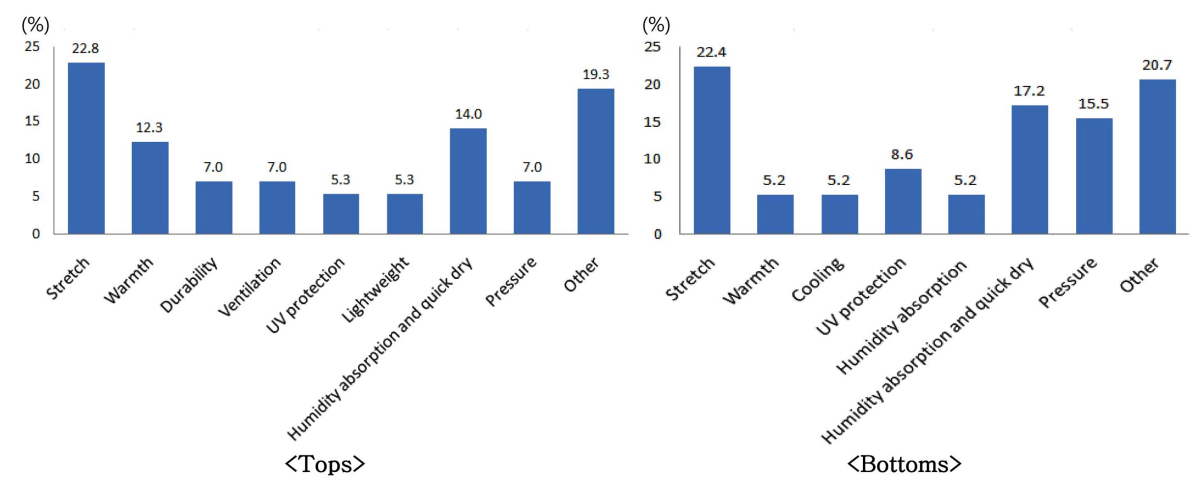

Fig. 6. Compression wear function types.

Table 6, Table 7에 제시하였다(ISO). 솔기를 최대한 납작하게 제작하여 착용감을 좋게 하고 공기의 저항을 최소화하기 위해 진동둘레, 상 - 하의 옆선, 몸판 절개선, 소매 절개선, 인심, 하 의 앞뒤중심선은 모두 무시접봉제인 오드람프로 봉제하였다. 몸 판밑단과 소매밑단은 소재를 한 번 접어 삼봉으로 처리한 제품 이 대부분이었다. 컴프레션웨어 봉제에 주로 사용되는 무시접 봉제나 웰딩기법 봉제는 기능성 소재에 최소한의 자극을 주고 운동 시 피부와의 마찰을 줄여 피부와 같은 부드러운 착용감으 로 운동 시 저항 요소를 최소화하고자 하는 목적이 있는 것으 로 분석되었다. 또한 상의는 $53 \%$ 가 배색봉사를 사용하였고 하
의는 $71 \%$ 가 배색봉사 디테일을 사용하여 근육 방향에 따른 절 개선을 배색컬러로 강조하기도 했다.

컴프레션웨어의 제품구성요소를 분석한 결과, 상의는 3 종류의 사이즈로, 하의는 4 종류의 사이즈로 생산 - 전개하는 제품이 가 장 많아 상의보다 하의의 사이즈 전개 범위가 넓은 것으로 나타 났다. 컴프레션웨어의 소재는 초경량성 고어텍스나 파워 스트레 치 소재로 많이 제작되었고 상의 배색감은 통기성 및 운동 시 활동성을 요하는 부위에 주로 사용되었고 하의 배색감은 운동 시 근육 및 관절 서포트가 필요한 부위에 주로 사용되는 것으로 분석되었다. 소재의 기능은 상의의 경우 신축성, 흡습속건, 보온

Table 6. Sewing methods of compression wear tops

\begin{tabular}{|c|c|c|c|c|c|c|c|c|}
\hline \multicolumn{2}{|r|}{ Category } & Neckline & Armhole line & Side line & $\begin{array}{l}\text { Bodice cutting } \\
\text { lines }\end{array}$ & Bodice hem & $\begin{array}{l}\text { Sleeve cutting } \\
\text { lines }\end{array}$ & Sleeve hem \\
\hline \multirow[b]{2}{*}{ Seam } & $\mathrm{N}$ & 8 & 13 & 9 & 12 & 12 & 7 & 8 \\
\hline & ISO No. & $\begin{array}{c}\text { ISO Number } \\
\begin{array}{r}1.01 .01 \\
\end{array}\end{array}$ & $\begin{array}{c}\text { ISO Number } \\
4.01 .02 \\
+\mathrm{H}\end{array}$ & $\begin{array}{c}\text { ISONumber } \\
4.01 .02 \\
+\mathrm{H}\end{array}$ & $\begin{array}{c}\text { ISO Number } \\
4.01 .02 \\
++ \\
\end{array}$ & $\begin{array}{c}\text { ISO Number } \\
6.02 .07 \\
+\square\end{array}$ & $\begin{array}{c}\text { ISO Number } \\
4.01 .02 \\
+\mathrm{H} \\
\end{array}$ & $\begin{array}{l}\text { ISO Number } \\
6.02 .07 \\
+1+\end{array}$ \\
\hline \multicolumn{2}{|r|}{ Frequency $(\%)$} & 38.1 & 72.2 & 100.0 & 75.0 & 67.6 & 38.9 & 50.0 \\
\hline & $\mathrm{N}$ & 8 & 15 & 9 & 16 & 11 & 15 & 15 \\
\hline
\end{tabular}

SO Number 605 ISO Number 607 ISO Number 607 ISO Number 607ISO Number 406ISO Number 607 ISO Number 406 Stitch ISO No. 3 Needle 5 Thread 4 Needle 6 Thread 4 Needle 6 Thread 4 Needle 6 Thread 2 Needle Bottom 4 Needle 6 Thread 2 Needle Bottom Coverstitch Coverstitch Coverstitch Coverstitch Converstitch Coverstitch Converstitch
Frequency $(\%)$
47.1
83.3
100.0
100.0
61.1
100.0
93.8

Table 7. Sewing methods of compression wear bottoms

\begin{tabular}{|c|c|c|c|c|c|c|c|}
\hline & Category & Waist & Center front and center back & Side line & Inseam & Leg cutting lines & Trouser hem \\
\hline \multirow{3}{*}{ Seam } & $\mathrm{N}$ & 23 & 22 & 19 & 19 & 20 & 23 \\
\hline & ISO No. & $\begin{array}{l}\text { ISO Number } \\
\begin{array}{c}7.03 .01 \\
+\end{array}\end{array}$ & $\begin{array}{l}\text { ISO Number } 4.01 .02 \\
+\mathrm{H}+\mathrm{H}\end{array}$ & $\begin{array}{c}\text { ISO Number } \\
4.01 .02 \\
+1+\end{array}$ & $\begin{array}{l}\text { ISO Number } \\
4.01 .02 \\
+++\end{array}$ & $\begin{array}{c}\text { ISO Number } \\
4.01 .02 \\
+++\end{array}$ & $\begin{array}{l}\text { ISO Number } \\
6.02 .07 \\
+1+\end{array}$ \\
\hline & Frequency (\%) & 47.8 & 77.3 & 78.9 & 78.9 & 80.0 & 65.2 \\
\hline \multirow{3}{*}{ Stitch } & $\mathrm{N}$ & 23 & 22 & 19 & 19 & 20 & 18 \\
\hline & ISO No. & $\begin{array}{l}\text { ISO Number } 406 \\
2 \text { Needle Bottom } \\
\text { Converstitch }\end{array}$ & $\begin{array}{c}\text { ISO Number } 607 \\
4 \text { Needle } 6 \text { Thread Coverstitch }\end{array}$ & $\begin{array}{c}\text { ISO Number } 607 \\
4 \text { Needle } 6 \text { Thread } \\
\text { Coverstitch }\end{array}$ & $\begin{array}{l}\text { ISO Number } 607 \\
4 \text { Needle } 6 \text { Thread } \\
\text { Coverstitch }\end{array}$ & $\begin{array}{l}\text { ISO Number } 607 \\
4 \text { Needle } 6 \text { Thread } \\
\text { Coverstitch }\end{array}$ & $\begin{array}{l}\text { ISO Number } 406 \\
2 \text { Needle Bottom } \\
\text { Converstitch }\end{array}$ \\
\hline & Frequency $(\%)$ & 39.1 & 100.0 & 94.7 & 100.0 & 100.0 & 78.3 \\
\hline
\end{tabular}


성, 통기성 등의 순으로 나타났고, 하의의 경우는 신축성, 흡습 속건, 압박성 등의 순으로 나타나 상의는 하의에 비해 보온성 이, 하의는 상의에 비해 압박성이 뛰어난 것을 알 수 있었다.

\section{3. 컴프레션웨어의 패턴 분석}

3.3.1. 제품치수와 부위별 신축률

컴프레션웨어의 운동 기능성 향상을 위해서는 인체공학적인 패턴과 운동 시 사용되는 근육과 관절의 위치를 기준으로 절개 된 패턴형태와 근육을 지지하고 운동 효과 증대를 위한 적절한 압박감이 매우 중요한 역할을 한다. 이러한 컴프레션웨어의 제

Table 8. Average compression wear product measurements Unit: $\mathrm{cm}$

\begin{tabular}{|c|c|c|c|c|}
\hline & & Category & Mean & S.D. \\
\hline \multirow{20}{*}{ Tops } & \multirow{12}{*}{$\begin{array}{c}\text { Horizontal } \\
\text { measurements }\end{array}$} & Shoulder width & 38.2 & 3.110 \\
\hline & & Front armhole center & 32.6 & 2.452 \\
\hline & & Back armhole center & 34.4 & 2.921 \\
\hline & & Chest width & 38.9 & 4.531 \\
\hline & & Waist width & 32.9 & 4.761 \\
\hline & & Hem width & 37.2 & 4.590 \\
\hline & & Neck width & 16.1 & 1.350 \\
\hline & & Upper sleeve width & 14.0 & 2.126 \\
\hline & & Folded sleeve width & 10.6 & 1.632 \\
\hline & & $\begin{array}{l}\text { gore under armhole length } \\
\text { (horizontal) }\end{array}$ & 7.5 & 2.291 \\
\hline & & $\begin{array}{l}\text { gore under armhole length } \\
\text { (vertical) }\end{array}$ & 6.8 & 0.751 \\
\hline & & Sleeve hem & 8.7 & 1.958 \\
\hline & \multirow{7}{*}{$\begin{array}{c}\text { Vertical } \\
\text { measurements }\end{array}$} & Shoulder slope & 4.2 & 2.048 \\
\hline & & Armhole length from HPS & 18.3 & 5.500 \\
\hline & & Waist location from HPS & 40.7 & 3.461 \\
\hline & & Front bodice length from HPS & 63.5 & 3.858 \\
\hline & & Back bodice length from HPS & 64.5 & 2.900 \\
\hline & & Front neck slope & 8.1 & 1.672 \\
\hline & & Back neck slope & 2.4 & 0.853 \\
\hline & Other & Sleeve length & 63.0 & 3.473 \\
\hline \multirow{12}{*}{ Bottoms } & \multirow{6}{*}{$\begin{array}{c}\text { Horizontal } \\
\text { measurements }\end{array}$} & Waist width & 29.4 & 2.825 \\
\hline & & Hip width & 36.8 & 2.013 \\
\hline & & Thigh width & 19.0 & 2.746 \\
\hline & & SKnee width & 16.2 & 1.250 \\
\hline & & Trouser hem width & 10.4 & 2.097 \\
\hline & & Trouser leg angle & 19.0 & 3.871 \\
\hline & \multirow{6}{*}{$\begin{array}{c}\text { Vertical } \\
\text { measurements }\end{array}$} & Total length & 86.1 & 3.238 \\
\hline & & Inseam & 64.6 & 3.764 \\
\hline & & $\begin{array}{l}\text { Front and back waistband height } \\
\text { difference }\end{array}$ & 3.4 & 1.325 \\
\hline & & Front crotch & 25.5 & 5.304 \\
\hline & & Back crotch & 26.8 & 5.722 \\
\hline & & Waistband height & 3.9 & 0.624 \\
\hline
\end{tabular}

품 사이즈 및 입체패턴의 형태, 부위별 패턴면적을 분석하기 위 해서 상의 중심 사이즈(95)8개, 하의 중심 사이즈(95) 7개 제품 의 사이즈를 측정하였고 그 평균을 Table 8에 제시하였다. 상 의 제품치수의 주요항목인 가슴너비는 평균 $38.9 \mathrm{~cm}$, 평균 허 리너비는 $32.9 \mathrm{~cm}$, 평균 밑단너비는 $37.2 \mathrm{~cm}$ 였고 표준편차가 4.5 이상으로 브랜드별 기준 치수 체계에 차이가 많은 것으로 분 석되었다. 또한 HPS(High Point Shoulder)로부터 뒷판 길이는 평균 $64.5 \mathrm{~cm}$, 윗소매통 너비는 평균 $13.7 \mathrm{~cm}$ 로 측정되었다.

하의 제품치수의 주요항목인 허리너비는 평균 $29.4 \mathrm{~cm}$, 평균 엉덩이너비는 $36.8 \mathrm{~cm}$, 평균 넙다리너비는 $19.0 \mathrm{~cm}$ 로 측정되었 고 앞밑위와 뒷밑위의 차이는 평균 $1.3 \mathrm{~cm}$ 로 나타났다.

컴프레션웨어는 일반 스포츠웨어보다도 수축 패턴을 사용하 여 부위별로 차별화된 의복압으로 근육의 긴장을 돕고 운동 시 적은 에너지로 운동효과를 높이고 압박에 의해 안정감을 주어 착용감을 좋게 한다. Table 9는 40대 표준 남성의 주요 인체 사이즈와 제품의 평균 사이즈를 비교한 결과이다. 상의에서는 가슴둘레가 평균 $18.7 \%$ 의 수축율을 보였고 밑단둘레는 $21.6 \%$ 의 수축율을 보여 가슴압박은 줄이고 밑단이 당겨 올라가지 않 도록 설계되었으며, 진동부위나 위팔부위는 운동량이 많은 부 위이므로 $10 \%$ 전후의 수축을 적용하였음을 알 수 있었다. 하 의에서는 허리둘레가 $28.2 \%$, 엉덩이둘레가 $22.6 \%$ 의 수축율을 나타내었고, 근육량이 많은 넙다리부위와 장딴지부위의 운동력 항상을 위해 34.4 38.6\%의 수축으로 강하게 압박하도록 설계 되었다. 현재 생산되고 있는 컴프레션웨어의 제품치수분석을 통 해 얻어진 부위별 수축율은 고기능성 컴프레션웨어의 최적 수 축율 패턴 개발에 활용할 수 있을 것이다.

\subsection{2. 피복 면적에 의한 신축률}

제품 사이즈를 측정한 상의 8 개, 하의 7 개 제품을 분해하여 제품 패턴 부위별 면적과 40대 남성 인체형상의 체표면적을 비

Table 9. Average size and contraction rate of main compression wear product areas

\begin{tabular}{llccc}
\hline Category & $\begin{array}{c}\text { Nude body } \\
(\mathrm{cm})\end{array}$ & $\begin{array}{c}\text { Sample } \\
\text { average }(\mathrm{cm})\end{array}$ & $\begin{array}{c}\text { Contraction } \\
\text { rate }(\%)\end{array}$ \\
\hline \multirow{3}{*}{ Chest girth } & 95.6 & 77.7 & 18.7 \\
& Hem girth & 94.9 & 74.5 & 21.6 \\
& Armhole girth & 42.5 & 37.5 & 11.7 \\
& Upper arm girth & 30.5 & 27.4 & 10.2 \\
& Elbow girth & 26.2 & 21.1 & 19.5 \\
& Wrist girth & 15.4 & 17.3 & -12.3 \\
\hline \multirow{4}{*}{ Bottoms } & Waist girth & 81.8 & 58.7 & 28.2 \\
& Hip girth & 95.0 & 73.5 & 22.6 \\
& Knee girth & 57.9 & 38.0 & 34.4 \\
& Thigh girth & 37.6 & 32.5 & 13.7 \\
Ankle girth & 38.1 & 23.4 & 38.6 \\
\hline
\end{tabular}


Table 10. Surface area of compression wear top patterns according to area

Unit: $\mathrm{cm}^{2}$

\begin{tabular}{cccccccccccccccc}
\hline & Category & P1 (Short-sleeved) & P2 (Short-sleeved) & S & C1 & C2 & U & N1 & N2 & Mean & S.D. \\
\hline & Neck band & 131 & 198 & - & 133 & 76 & - & 140 & 92 & 128 & 42.546 \\
& Front bodice & 1510 & 1817 & 1578 & 1972 & 2286 & 994 & 2089 & 2081 & 1791 & 415.717 \\
\multirow{2}{*}{$\begin{array}{c}\text { Pattern } \\
\text { surface } \\
\text { area }\end{array}$} & Back bodice & 3067 & 2183 & 1557 & 860 & 1602 & 1779 & 2030 & 2948 & 2003 & 734.482 \\
& Side piece & - & - & 858 & 1441 & 229 & 606 & 1074 & 783 & 832 & 411.491 \\
& Shoulder & - & 149 & 123 & - & - & - & - & - & 136 & 18.546 \\
& Sleeve & 1507 & 2108 & 2601 & 2279 & 2582 & 1852 & 2435 & 3360 & 2340 & 556.265 \\
\hline \multicolumn{2}{c}{ Body surface area } & 6215 & 6455 & 6717 & 6684 & 6774 & 5232 & 7767 & 9265 & 6889 & 1188.528 \\
\hline \multicolumn{2}{c}{ Contraction rate $(\%)$} & 8150 & 6821 & 8259 & 8044 & 7833 & 7515 & 9143 & 9554 & 8040 & 937.424 \\
\hline
\end{tabular}

Table 11. Surface area of compression wear bottom patterns according to area Unit: $\mathrm{cm}^{2}$

\begin{tabular}{|c|c|c|c|c|c|c|c|c|c|c|}
\hline & Category & $\mathrm{P}$ & $\mathrm{O}$ & U1 & $\mathrm{U} 2$ & $\mathrm{~S}$ & $\mathrm{C}$ & N (Bermuda length) & Mean & S.D. \\
\hline \multirow{8}{*}{$\begin{array}{c}\text { Pattern } \\
\text { surface } \\
\text { area }\end{array}$} & Waistband & 240 & 235 & 256 & 208 & 241 & - & 305 & 247 & 32.281 \\
\hline & Front leg & 2571 & 3136 & 3057 & 1663 & 2178 & 2113 & 1196 & 2273 & 708.748 \\
\hline & Back leg & 2526 & 3321 & 2391 & 2272 & 2210 & 2710 & 176 & 2230 & 979.308 \\
\hline & Side piece & - & - & - & 581 & 480 & 1156 & 1933 & 1038 & 667.077 \\
\hline & Inseam & - & - & - & - & - & - & 260 & - & - \\
\hline & Sole & - & - & - & 354 & - & - & - & - & - \\
\hline & Other band & - & - & - & - & - & - & 34 & - & - \\
\hline & Total surface area & 5337 & 6691 & 5703 & 5079 & 5108 & 5979 & 3903 & 5400 & 868.606 \\
\hline \multicolumn{2}{|c|}{ Body surface area } & 8285 & 8442 & 8320 & 8466 & 8093 & 7781 & 4590 & 7711 & 1396.297 \\
\hline \multicolumn{2}{|c|}{ Contraction rate $(\%)$} & 68.1 & 79.3 & 68.5 & 60.0 & 63.1 & 76.8 & 85.0 & 70.0 & 9.082 \\
\hline
\end{tabular}

교한 결과 Table 10, Table 11과 같이 나타났다. 상의의 경우, $\mathrm{P}$ 사 제품 이외에는 모두 10 부 소매의 중심 사이즈(95)임에도 불구하고 전체 면적에 큰 차이를 보였다. 가장 면적이 넓은 $\mathrm{N}$ 사제품과 가장 면적이 좁은 U사제품의 면적은 $4033 \mathrm{~cm}^{2}$ 나 차 이를 보여 컴프레션웨어 상의 면적은 브랜드별 - 제품별로 큰 차이를 나타냈고 하의의 면적은 제품별 차이가 상의보다는 적 은 것을 알 수 있었다. 컴프레션웨어 상의의 경우 평균 $85.7 \%$ 의 신축률을 나타냈고 하의는 평균 $70.0 \%$ 의 신축률을 나타내 상의보다 하의의 패턴 신축률이 큰 경향을 보였다.

\subsection{3. 올방향과 패턴수}

분석한 제품(상의 8 개, 하의 7개) 중, 일부 제품의 분해사진 과 패턴전개도를 Table 12에 예시로 나타내었고, Table 13에는 상-하의 주요 부위별 올방향의 빈도를 나타내었다. 상의의 경 우 푸서방향보다는 식서방향으로 재단된 제품의 빈도가 높았으 나 몸판 측면과 소매에서는 $40 \%$ 이상이 푸서방향으로 재단된 것을 알 수 있었다. 상의는 적게는 7 개, 많게는 25 개의 패턴으 로 구성되었고 평균 13 개의 패턴으로 제품이 구성되었다.

하의의 경우 측면을 제외하고는 식서방향과 푸서방향으로 재 단된 빈도수가 같았고, 측면은 식서방향보다는 푸서방향으로 재 단되어 앞- 뒤 근육을 잡아주는 역할을 하였다. 또한 하의의 하복부, 넙다리, 엉덩이 부위의 경우 바이어스로 재단되어 근육
Table 12. Example of compression wear product disassembly

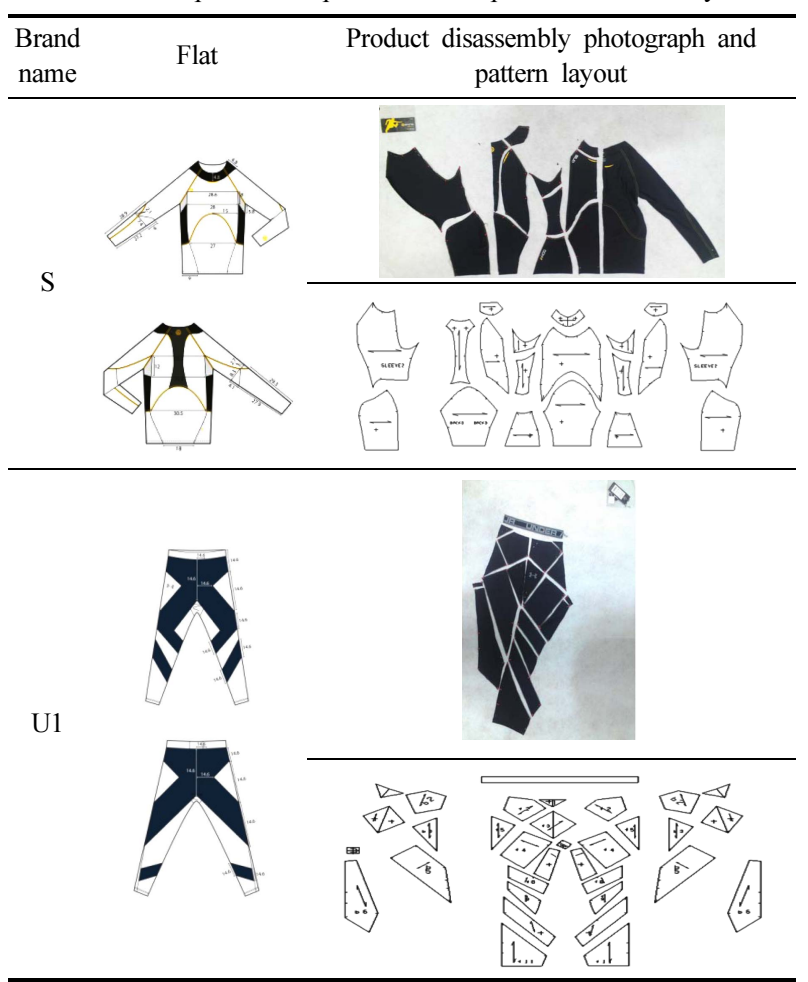


Table 13. Cutting direction of main compression wear parts Unit: \%

\begin{tabular}{llccc}
\hline & Area & Lengthwise & Crosswise & Bias \\
\hline \multirow{4}{*}{ Tops } & Front bodice & 71.4 & 28.6 & \\
& Back bodice & 66.7 & 33.3 & \\
& Side & 60.0 & 40.0 & \\
& Shoulder & 62.5 & 37.5 & \\
& Sleeve & 55.6 & 44.4 & \\
\hline \multirow{4}{*}{ Bottoms } & Lower abdomen & 42.9 & 42.9 & 14.3 \\
& Side & 42.9 & 42.9 & 14.3 \\
& Thigh (Front) & 50.0 & 50.0 & \\
Hip & 42.9 & 57.1 & \\
Thigh (back) & 42.9 & 42.9 & 14.3 \\
Calf & 50.0 & 42.9 & 14.3 \\
\hline
\end{tabular}

의 방향과 움직임에 도움을 주는 제품들도 있었다. 하의는 적 게는 8 개, 많게는 32 개의 패턴으로 구성되었고 평균 18 개의 패 턴으로 제품이 구성되었다.

\subsection{4. 가상 착의에 의한 패턴 변형}

Table 14, Table 15는 40대 표준 남성 인체형상을 기준으로 가상착의법에 의한 상-하의 컴프레션웨어의 패턴변형 분석 결 과이다. 변형분포도의 컬러를 보면 부위별 압박정도가 다르며 제품별 차이도 확연히 나타나는 것을 알 수 있다. 상의의 경우 어깨, 배, 밑단이 다른 부위에 비해 변형율이 높은 것을 알 수 있고 하의는 엉덩이, 넙다리, 장딴지가 다른 부위에 비해 변형 율이 높은 것을 알 수 있었다. 상의에서 $31.4 \%$ 의 가장 높은 변형율을 보인 $\mathrm{U}$ 사 제품과 $3.0 \%$ 로 변형율이 가장 낮은 $\mathrm{N}$ 사 제품은 변형분포도의 부위별 압박 컬러에서 확연한 차이를 나 타내는 것을 확인했다. 하의는 상의보다 $15.7 \%$ 패턴 변형율이 높은 결과를 나타낸 것과 같이 대부분의 제품이 강한 압박으로 붉게 표현되었다. $40.0 \%$ 로 가장 높은 변형율을 나타냈던 U사 제품은 부위별 압박의 구분없이 전 부위에서 매우 강한 변형율 을 보였다. 이와 같이 패턴면적과 체표면적의 차이에서 나타난 신축률의 결과를 가상 착의법의시각적 분석을 통해 재확인할 수 있었다.

이상과 같이 현재 생산되고 있는 컴프레션웨어의 패턴 분석

Table 14. Analysis results of compression wear tops through virtual fitting

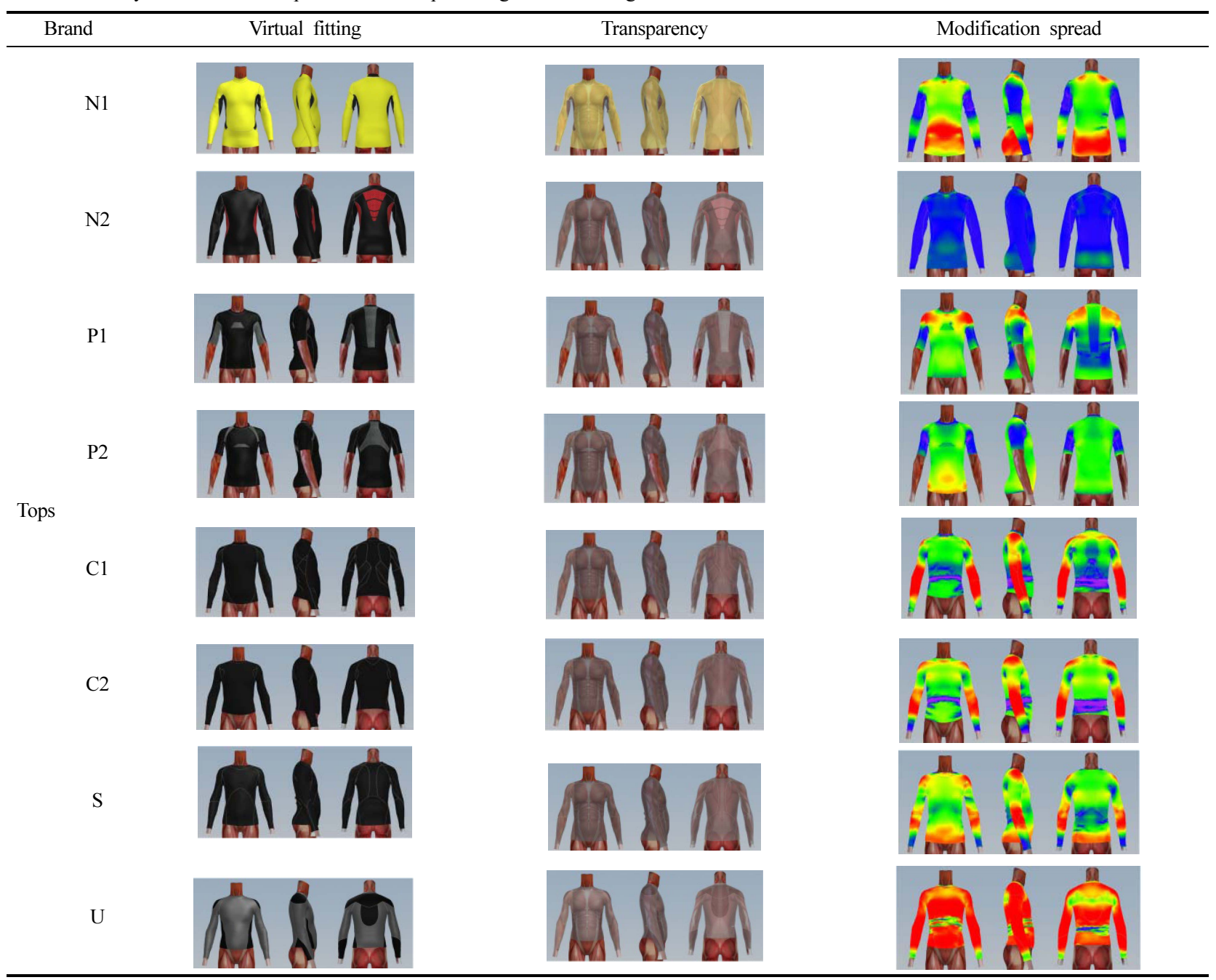


Table 15. Analysis results of compression wear bottoms through virtual fitting

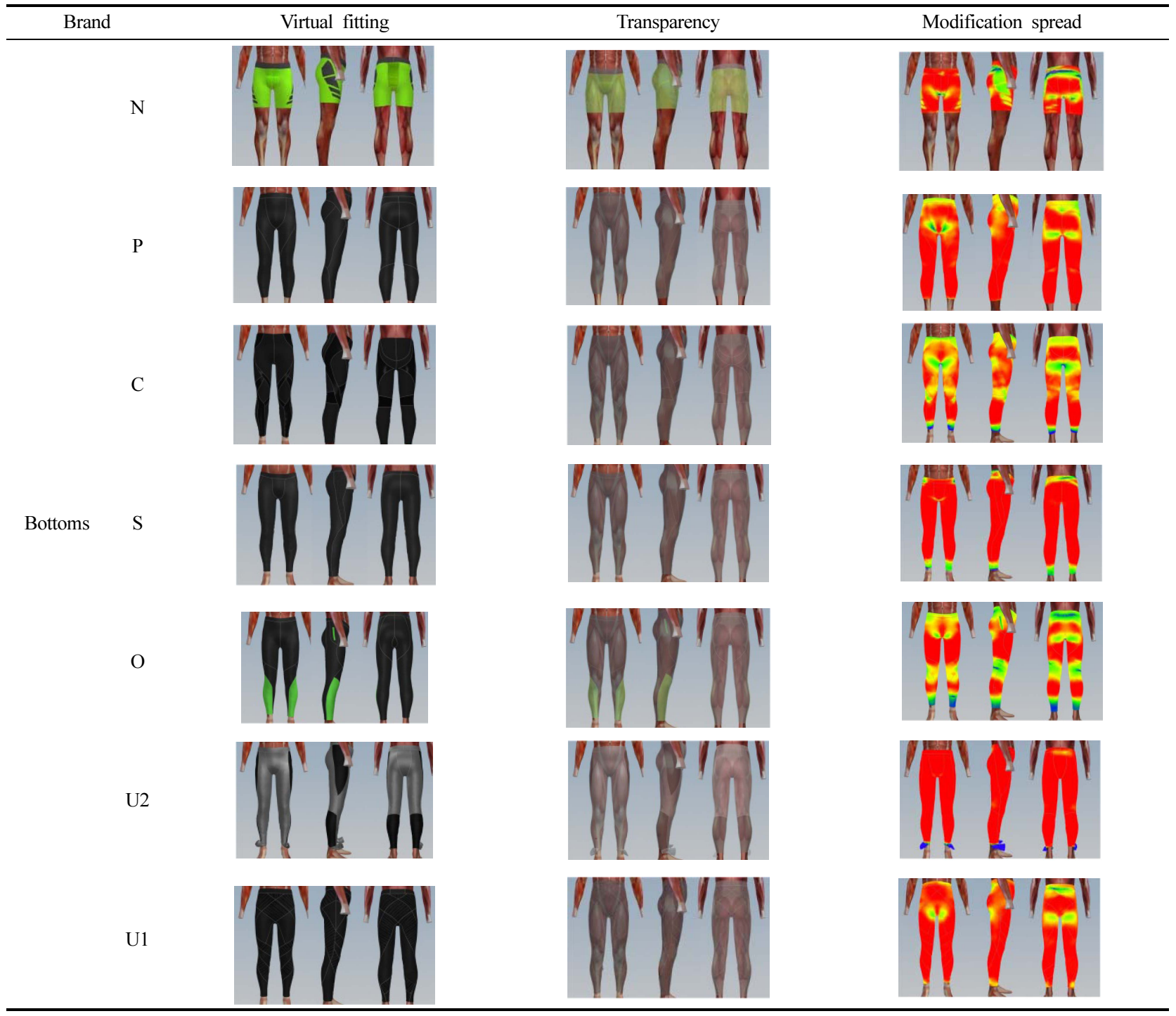

결과, 상의 면적에 비해 하의 면적이 좁은 것으로 나타났고 상 의는 식서방향을 중심으로 재단 되어진 것에 비해 하의는 식서 방향은 물론 푸서방향과 바이어스방향으로 재단되어진 제품도 많은 것으로 나타났다. 상의는 13 개, 하의는 18 개의 유기적으 로 연결된 패널들로 구성되어 동작 기능성을 향상시키는 것으 로 분석되었고 피복면적에 관한 평균 신축률은 상의가 $85.7 \%$, 하의가 $70.0 \%$ 의 신축률을 나타냈다. 그 중 가슴둘레가 평균 $18.7 \%$, 밑단둘레가 $21.6 \%$ 의 수축율을 보였고 하의에서는 허리 둘레가 $28.2 \%$, 엉덩이둘레가 $22.6 \%$ 의 수축율을 나타내었으며 근육량이 많은 넙다리부위와 장딴지부위는 34.4 38.6\%의 수축 으로 강하게 압박하도록 설계되어 상의에 비해 하의의 패턴 변 형율이 높게 설계된 것으로 파악되었다. 이러한 컴프레션웨어 피복면적 및 신축률 결과는 컴프레션웨어 개발 시 패턴면적과 부위별 재단방향의 차별화를 통해 부위별 기능성을 부여할 수 있는 기초 자료가 될 수 있을 것이다.

\section{4. 결 론}

본 연구에서는 컴프레션웨어 생산브랜드를 대상으로 컴프레 션웨어 제품 개발에 필요한 정보를 제공하고자 하는 목적으로 현재 국내외에서 전개 중인 컴프레션웨어 생산브랜드 14 개의 제품 중에서 상의 18 개와 하의 23 개에 대한 절개선의 위치와 수를 중심으로 한 디자인분석, 생산사이즈, 가격, 소재 등을 중 심으로 한 제품구성요소 분석하였다. 또한 컴프레션웨어 생산 브랜드 중 인지도가 있는 상의 8 개, 하의 7 개를 선별하여 제품 치수와 패턴면적에 따른 신축률과 재단방향 등의 패턴설계 경 향을 분석하였고 그 결과는 다음과 같다.

첫째, 컴프레션웨어의 디자인은 인체에 밀착되어 착용감에 최대한 영향을 주지 않고 인체의 근육 움직임을 고려하여 설계 된 절개선을 응용한 디자인이 대부분이었다. 상의는 평균 14 개 의 절개선으로 구성되었고 그 중 가로 절개선이 3 개, 세로 절 
개선이 11 개로 나타났고, 하의는 평균 15 개의 절개선으로 구성 되었고 그 중 가로 절개선이 5 개, 세로 절개선이 10 개로 나타 났으며 각 절개선은 근육과 관절의 위치를 고려하여 설계되었 음을 알 수 있었다.

둘째, 생산되어지고 있는 제품 사이즈의 경우 상의는 3종류의 사이즈로, 하의는 4 종류의 사이즈로 전개하는 제품이 가장 많아 상의보다 하의의 사이즈 전개 범위가 넓은 것으로 분석되었다. 컴프레션웨어의 소재는 초경량성 고어텍스나 파워 스트레치 소 재로 많이 제작되었고 상의 배색감은 통기성 및 운동 시 활동성 을 요하는 부위에 주로 사용되었고 하의 배색감은 운동 시 근육 및 관절 서포트가 필요한 부위에 주로 사용되는 것으로 분석되 었다. 소재의 기능은 상의의 경우 신축성, 흡습속건, 보온성, 통 기성 등의 순으로 나타났고, 하의의 경우는 신축성, 흡습속건, 압 박성 등의 순으로 나타나 상의는 하의에 비해 보온성이, 하의는 상의에 비해 압박성이 뛰어난 것을 알 수 있었다.

섯째, 컴프레션웨어의 상의 패턴면적에 비해 하의 패턴면적이 좁은 것으로 나타났고 상의는 식서방향을 중심으로 재단되어진 것에 비해 하의는 식서방향은 물론 푸서방향과 바이어스방향으 로 재단 되어진 제품도 많은 것으로 나타났다. 상의는 13 개, 하 의는 18 개의 유기적으로 연결된 패널들로 구성되어 동작 기능성 을 항상시키는 것으로 분석되었고 피복면적에 관한 평균 신축률 은 상의가 $85.7 \%$, 하의가 $70.0 \%$ 의 신축률을 나타나 상의에 비 해 하의의 패턴 변형율이 높게 설계된 것으로 파악되었다.

본 연구는 컴프레션웨어의 다양한 제품을 조사- 분석하여 현재 컴프레션웨어의 제품구성요소의 특성을 파악하고 제품의 패턴전개에 따른 패턴 절개선 구성과 사이즈 스펙을 분석하여 성장 가능성이 높은 컴프레션웨어 개발에 필요한 유용한 정보 를 제공하고 컴프레션웨어 개발 방향을 제시하였다. 나아가 인 체의 근육패턴과 관절부위를 기초한 절개선 설정 및 패턴의 블 록화, 제품의 부위별 수축율은 입체패턴 전개를 통한 컴프레션 웨어 기준패턴 생성의 기초 자료가 되며, 블록화한 패턴의 소 재 선정 및 재단방향에 따라 부위별 기능성을 달리할 수 있는 맞춤형 컴프레션웨어를 개발할 수 있을 것이다. 또한 현대인의 건강과 레저에 대한 지속적인 관심증가에 따른 컴프레션웨어 시장의 확대는 기능적 측면을 부각한 연령층별 컴프레션웨어 상품은 물론 디자인 측면까지 만족할 수 있는 다양한 제품의 개발로 이어지길 기대해 본다.

\section{감사의 글}

본 논문은 정보통신산업진흥원 2012년 3D 및 스마트TV 기술 적용 시범사업(과제명: $3 \mathrm{D}$ 소비자 체형분석 및 Pop-up Fashion
Store 개발)의 지원에 의해 연구되었음.

\section{References}

Baik, C. E., \& Kim, S. Y. (2005). Study on the fabric trend in hi-tech functional active sportswear. Journal of the Korea Fashion \& Costume Design Association, 7(1), 55-64.

Cha, Y. M. (2013). A study on three-dimensional design of cycle clothing using $3 D$ motion analysis system-Focused on men's upper garments-. Unpublished doctoral dissertation, Konkuk University, Seoul.

Choi, J. H., \& Kim, M. J. (2011). Clothing and Health. Seoul: Kyomunsa.

Choi, M. S. (2004). An exploratory research on pattern development of bicycle apparel for cyclists. Journal of the Korean Society of Clothing Textiles, 28(5), 637-647.

Fitenbody \& Dong Seoul College. (2009). Development of dummy for man's pattern making and prptotype pattern for apparel pattern making of the sports and casual wear Industries. Sungnam: Academy. Institute. Government exchanges and cooperation projects.

Jeong, Y. H., \& Hong, K. H. (2006). Development of 2D tight-fitting pattern from 3D scan data. Journal of the Korean Society of Clothing and Textiles, 30(1), 157-166.

Jeong, Y. H., Kim, S. H., \&Yang, Y. M. (2010). Development of tightfitting garments with a portable ECG monitor to measure vital signs. Journal of the Korean Society of Clothing Textiles, 34(1), 112-125.

Kim, S. Y. (2008). Engineering design process of tight-fit performance sportswear using $3 D$ information of dermatomes and skin deformation indynamic posture. Unpublished doctoral dissertation, Chungnam National University, Daejeon.

Kim, T. G., Park, S. J., Park, J. W., Suh, C. Y., \& Choi, S. A. (2012). Technical design of tight upper sportswear based on 3D scanning technology and stretch property of knitted fabric. Journal of the Korean Society for Clothing Industry, 14(2), 277-285. doi:10.5805/ KSCI.2012.14.2.277

Kim, N. Y. (2012). Engineering design of 3D compression suitbased on the anatomical nature of moving body. Unpublished master's thesis, Chungnam National University, Daejeon.

Koo, Y. S. (2011). The effect of compression wear for the sport performance and muscle function. Textile Coloration and Finishing, 23(1), 60-68.

Lee, E. J., \& Baik, C. E. (2008). A study on the fabric trend in sport wear. Journal of the Korea Fashion \& Costume Design Association, 10(3), 47-59.

'Reasons behind the tight 'compression wear' sportswear trend'. (2013, May 8). Donga Ilbo. from http://news.donga.com

(Received 19 February 2014; 1st Revised 18 March 2014; 2nd Revised 30 April 2014; Accepted 10 May 2014)

Copyright (C) 2014 (by) the authors. This article is an open access article distributed under the terms and conditions of the Creative Commons Attribution license (http://creativecommons.org/licenses/by/3.0/), which permits unrestricted use, distribution, and reproduction in any medium, provided the original work is properly cited. 